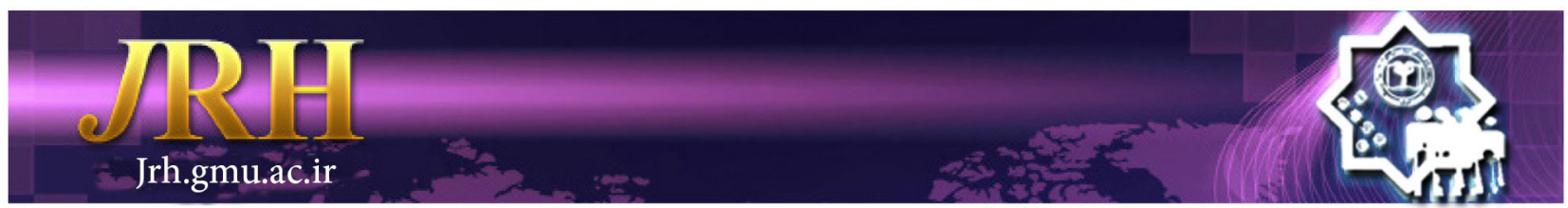

\title{
The impact of children's entry to labor market on health expenditures of urban household
}

\author{
Mahdi Shahraki ${ }^{1}$, Simin Ghaderi ${ }^{1}$
}

\author{
Journal of Research \& Health \\ Social Development \& Health Promotion \\ Research Center \\ Vol. 9, No. 5, Sep \& Oct 2019 \\ Pages: $428-436$ \\ DOI: $10.29252 / j r h .9 .5 .428$ \\ Original Article
}

1. Department of Economics, Faculty of Management and Human Science, Chabahar Maritime University, Chabahar, Iran

Correspondence to: Mahdi Shahraki, Department of Economics, Faculty of Management and Human Science, Chabahar Maritime University, Chabahar, Iran

Email: shahraki.mehdi@gmail.com

Received: 16 Jun 2018

Accepted: 20 Nov 2018

How to cite this article: Shahraki M, Ghaderi S. The impact of children's entry to labor market on health expenditures of urban household. J Research Health2019; 9(5): 428- 436.

\begin{abstract}
Child labor is regarded as an ambiguous and controversial challenge encountered in majority of countries across the world. Given the incidence and prevalence of this phenomenon in Iran and the importance of household health expenditures, this study was done to evaluate the impact of children's entry into labor market on household health expenditures. This study was conducted on urban households living in all provinces in Iran in 2016. The sample size was estimated 6517 households. The statistics of these households were extracted from the raw data of income-cost of urban households. The probit and ordered probit econometric models were also used to estimate the coefficients of the model. The results showed that the entry of children into labor markets in both models had a positive impact on household health expenditures. Therefore, making policies for eliminating child labor, compensating the income they got from working, and providing the possibility of further education for these children were of utmost importance. Household income per capita, family size, father's age, and parental education had also a positive and significant effect on household health expenditures. Moreover, parental employment in private sector could increase household health expenditure, but such costs could be decreased if parents were employed in public sector.
\end{abstract}

Keywords: Child, Employment, Health Expenditures, Income

\section{Introduction}

As an ambiguous and controversial challenge, child labor is currently regarded as a phenomenon encountering in the majority of countries across the world since working not only reduces physical and mental health status in children but also downgrades their levels of education, sense of liberty, and well-being [1]. Considering the total population of children aged 7-14 years old all over the world, $9.6 \%$ of them are considered as child labor and $4.6 \%$ of this age group is involved in high-risk occupations [2]. The given phenomenon is not deemed as an exception in Iran. In this respect, nearly $20 \%$ of girls and $22 \%$ of boys in the age range of $10-18$ years old are entering to labor market [3]. It is argued that damage to children's physical and mental health can also make them vulnerable to health-related risks [4,5]. In this respect, pressures from 
physical work affecting the growth of bones and joints can similarly lead to damage to the spinal cord and consequently cause stunted growth [6]. Moreover, increased risks of exposure to pesticides, chemical substances, dusts, and so forth are likely to heap on the risks of infection with bronchitis, cancer, and other diseases [5,7]. All of these risks are assumed much higher for children suffering from malnutrition [4].

Accordingly, various reasons have been raised for child labor, including parental coercion, levels of education in children and their parents, household income, family size, maternal employment, gender, etc. [8-11]. Regardless of the causes of child labor, this phenomenon and its consequences especially its impact on household health expenditures are of utmost importance because identifying the factors affecting household health expenditures can be a useful tool for policy makers and health system planners to manage or reduce health costs.

According to theoretical principles, various factors affect household health expenditures. Determinants of household health expenditures are generally classified into two groups; namely, supply-side and demand-side factors. Demand-side factors include income, wealth, unemployment rate, education, urbanization, and family size; and supply-side factors include physicians, beds, dentists, pharmacists, and pharmacies [12-17]. The present study investigated demand-side factors at the microeconomics level.

At the micro level, the health expenditures modeling dates back to a research by Grossman who found that the education, age, and wage rates affected the health demand and household health expenditures $[18,19]$. Income is a determinant of household health expenditures as it enables people to purchase health goods and services [13,18-24]. "Education" is another determinant of household health expenditures with positive or negative impact. When the education level increases, people will have higher knowledge about their health needs and will use preventative health services to have less need for costly health services in the future. Based on this approach, higher education levels increase health costs in the short term, but decrease health costs in the long term [12,20,23,25]. Furthermore, given physical differences between male and female members of households, gender differences can lead to different health expenditures in households [19]. In most studies, gender is a variable in the vector of demographic variables affecting health expenditures of households [19,22,23,26,27]. Age structure, family size, insurance, and location are other factors affecting household health expenditures [19,20,22,23,27,28]. Considering what mentioned above, main determinants of household health expenditures are divided into three categories as follows: 1- Economic factors (income, insurance, and wealth), 2Social factors (education, geographic location, and marital status), and 3-Demographic factors (family size, gender, and age structure)

Like many developing countries, a large share of health expenditures is provided by households' direct payments in Iran [19,23]. In other words, individuals directly pay expenditures of health goods and services. This kind of financing is called "Out of Pocket Payment". Given the important role of individuals and families in health payments, and given that the reduction of direct payments of households is an important goal of health policies in any countries such as Iran, it is essential to identify and analyze determinants of households' direct payments or health expenditures. Given the incidence and prevalence of child labor phenomenon, the importance of managing household health expenditures and the share of out of pocket payments for goods and services, the main objective of this study was firstly to examine the impact of children's entry to the labor market on urban household health expenditures and secondly to identify factors affecting urban household health expenditures at microeconomic level. In addition, taking the theoretical foundations and the results of empirical studies into account, the present study was done to answer the following questions: "How does children's entry into labor market affect health expenditures of urban households?" and "What other factors can 
influence urban household health expenditures?" A great number of studies have been conducted on identification of determinants of household health expenditures at macroeconomic level, but few studies have been done at the microeconomic level. The present study was conducted at the microeconomic level using data of urban households in all provinces of Iran. Since the aim of this research was to examine the impact of children's entry into the labor market on urban household health expenditures, the impact of children's economic, social, and demographic characteristics on household health expenditures was also measured.

\section{Method}

The present study was an applied research in objective and a correlational research considering method that uses the Probit and Ordered Probit econometric models to evaluate the impact of children's entry into labor markets on health status of households. The statistical population of this study included all urban households living in Iran's provinces (all provinces) in 2016. The sample size consisted of the number of households selected according to Cochran's formula and three-stage sampling method presented by the Statistical Center of Iran. At the first step, 75 sample cities from all the provinces were chosen according to the final amendment of plans of the economic statistics office. At the second step, some blocks were chosen among the listed blocks in the sample cities using systematic sampling method. At the third step, sample households were selected by systematic sampling in each selected block. Only those households with at least one child aged $10-18$ years were selected whose total statistics required for this research were also available. According to these conditions, 6517 households were selected. The required data of the households such as the study sample were also extracted from different sections of cost-income raw data for urban households in Iran in 2016 and then analyzed in the Microsoft Excel software. To reflect on the study subject, a regression model was explained as follows and the coefficients of the model were estimated based on Probit and Ordered Probit models in the Stata software. The dependent variable was the urban household health expenditures in the Iranian rial. In the Probit econometric model, this variable had two values of zero and one considered for households whose health expenditures was less than the mean of the sample and for the rest, respectively. To better investigate the study subject and to make the sample size more homogenous, households were divided into five categories based on their health expenditures and with reference to their means and standard deviations. Each category had one number and the order of the given categories was also very important, i.e. the higher the household health expenditures, the higher the number of the categories. In this case, the dependent variable had five values, then the Ordered Probit Model was employed to estimate the coefficients of the model. The independent variables of the model and the coding methods were also illustrated in Table 1.

\section{Results}

The mean of household health expenditures was $1,288,811 \pm 283,491$ Iranian Rials per month in which $76 \%$ of the households had spent health costs and expenditures lower than the mean and $24 \%$ of them had done spent health costs and expenditures than the mean. Among the participants, $53 \%$ were boys and $47 \%$ were girls, of which only $6 \%$ were child laborers, $89 \%$ were school children, and 5\% were neither laborers nor school students. The mean age of fathers and mothers in the households was 40.5 and 45.5 years, respectively. Father's level of education were higher than those of mother's in the households. Furthermore, 10\% of mothers were employed.

The results of the Probit Econometric Model were presented in Table 2. Accordingly, the age of father, mother, and child could have a positive impact on household health expenditures. The increase in father's age could also raise household health expenditures by $0.2 \%$ considering a $5 \%$ significance level. To examine the effect of child labor on household health expenditures, two variables of "child labor" and "school 
children" were used and the coefficients of the variables indicated that households with child labor had higher health expenditures and those with school children had lowered health costs. Therefore, having a child laborer would increase the household health expenditures by $0.3 \%$ and having a school child had reduced such costs by $1.5 \%$.

Table 1: Independent Variables and coding

\begin{tabular}{|c|c|}
\hline Variable & Coding \\
\hline Income Per Capita & Rials \\
\hline Child's Gender & Boy $=1$, Girl $=0$ \\
\hline Child's Age & Child 's Age in Year \\
\hline Child labor & Employed Child $=1$, Otherwise $=0$, \\
\hline School Children & Schooling Child $=1$, , Otherwise $=0$ \\
\hline Child's Education & Primary and Lower $=1$, Secondary $=2$, Diploma Degree $=3$ \\
\hline Father's Age & Father's Age in Year \\
\hline Father's Education & $\begin{array}{l}\text { Primary and Lower }=1, \text { Secondary }=2 \text {, Diploma Degree }=3 \text {, Associate Degree }=4 \text {, Bachelor } \\
\text { Degree }=5 \text {, MSc. Degree }=6, \mathrm{Ph} . \text { D. Degree and Higher }=7\end{array}$ \\
\hline Father's Wage & Father's Wage Per Hours \\
\hline Father's Public Employment & Employed Father in Public Sector $=1$, Otherwise $=0$, \\
\hline Father's Private Employment & Employed Father in Private Sector $=1$, Otherwise $=0$, \\
\hline Mother's Age & Mother's Age in Year \\
\hline Mother's Education & $\begin{array}{l}\text { Primary and Lower }=1, \text { Secondary }=2 \text {, Diploma Degree }=3 \text {, Associate Degree }=4 \text {, Bachelor } \\
\text { Degree }=5 \text {, MSc. Degree }=6, \text { Ph.D. Degree or Higher }=7\end{array}$ \\
\hline Mother's Employment & Employed Mother $=1$, Otherwise $=0$ \\
\hline Mother's Head & Mother is the head of household $=1$, Otherwise $=0$ \\
\hline Mother's Wage & Mother's Wage Per Hours \\
\hline Mother's Public Employment & Employed Mother in Public Sector $=1$, Otherwise $=0$, \\
\hline Mother's Private Employment & Employed Mother in Private Sector $=1$, Otherwise $=0$, \\
\hline Family Size & Number of Family Members \\
\hline
\end{tabular}

Source: Authors' findings

Parental education, at a $1 \%$ significance level, could have a positive impact on household health expenditures; so that the increase in the levels of education in fathers and mothers could respectively add to health expenditures by $0.16 \%$ and $0.19 \%$. It should be noted that parents' wages did not have a statistically significant effect on household health expenditures. Moreover, father's employment in public sector could reduce health expenditures by $3.7 \%$ and their employment in private sector was likely to increase household health expenditures by $3.6 \%$. Similarly, mother's employment in private sector could boost household health expenditures. Mother's employment and mother's head were not statistically significant and these results could not be interpreted. Family size or the number of household members could also have a positive impact on household health expenditures; in this respect, the addition of a new member to the household could lead to an increasing trend in household health expenditures by $0.8 \%$. Household income per capita also influenced household health expenditures positively and significantly at a $1 \%$ significance level, so that the rise in household income per capita led to an ascending trend in household health expenditures by $4 \%$.

To make households much more homogenous and to better examine this issue, the sample households were divided into five categories based on their health expenditures and according to their means and standard deviations. Given that the order of the ranks 
assigned to the dependent variables in the Ordered Probit Model is very important, the households having higher health expenditures were placed in higher categories, so that a household whose health expenditures was less than the mean of the sample was put in the first category, ones whose health expenditures was one standard deviation higher than the mean of the sample was placed in the second category, and the households whose health expenditures was two, three, and four standard deviations higher than the mean of the sample were assigned to the third, the fourth, and the fifth categories; respectively.

Table 2 The coefficients and marginal effects of the Probit Model

\begin{tabular}{lccccc}
\hline & Coefficients & Standard Deviations & Probability & Marginal effects & Probability \\
\hline Income Per Capita & 0.1299 & 0.0266 & 0.0000 & 0.0400 & 0.0000 \\
Child's Gender & 0.0234 & 0.0351 & 0.5050 & 0.0072 & 0.5050 \\
Child's Age & 0.0004 & 0.0136 & 0.9740 & 0.0001 & 0.9740 \\
Child labor & 0.0109 & 0.0951 & 0.0909 & 0.0033 & 0.0909 \\
School Children & -0.0497 & 0.0762 & 0.0514 & -0.0153 & 0.0514 \\
Child's Education & -0.0157 & 0.0280 & 0.5740 & -0.0048 & 0.5740 \\
Father's Age & 0.0076 & 0.0037 & 0.0430 & 0.0023 & 0.0430 \\
Father's Education & 0.0519 & 0.0147 & 0.0000 & 0.0160 & 0.0000 \\
Father's Wage & 0.0000 & 0.0000 & 0.9700 & 0.0000 & 0.9700 \\
Father's Public Employment & -0.1201 & 0.0592 & 0.0430 & -0.0370 & 0.0420 \\
Father's Private Employment & 0.1199 & 0.0434 & 0.0060 & 0.0369 & 0.0060 \\
Mother's Age & 0.0065 & 0.0042 & 0.1260 & 0.0020 & 0.1260 \\
Mother's Education & 0.0620 & 0.0153 & 0.0000 & 0.0191 & 0.0000 \\
Mother's Employment & -0.0763 & 0.0760 & 0.3160 & -0.0235 & 0.3160 \\
Mother's Head & 0.0086 & 0.0880 & 0.9220 & 0.0026 & 0.9220 \\
Mother's Wage & 0.0000 & 0.0000 & 0.4180 & 0.0000 & 0.4180 \\
Mother's Public Employment & -0.1320 & 0.1123 & 0.2400 & -0.0406 & 0.2400 \\
Mother's Private Employment & 0.2190 & 0.1021 & 0.0320 & 0.0674 & 0.0320 \\
Family Size & 0.0271 & 0.0156 & 0.0830 & 0.0083 & 0.0830 \\
Cons & -3.7670 & 0.5205 & 0.0000 & & \\
\hline
\end{tabular}

Estimated coefficients and marginal effects of Ordered Probit Model were shown in Table 3. The coefficients of the model were employed only to evaluate the positive and negative relations and the marginal effects were used to examine the changes of the independent variables on the dependent ones [3,29-32]. The coefficient of "Child Labor" variable was positive and the one for school child variable was reported negative; that is, child labor could increased household health expenditures and schooling caused a reduction in such costs. The marginal effects of child labor also revealed that child labor had a positive impact on health expenditures in households with high health expenditures, so that the households of categories 2, 3, 4, and 5 having child labor had increased their household expenditures by
$0.02,0.01,0.001,0.001 \%$; respectively. The coefficients of the marginal effects for "School Children" showed that households, whose children were studying, were spending less on health compared to the ones whose children were not studying, but working. The child's schooling in the households of categories 2, 3,4 , and 5 could also lower household health expenditures by $0.20,0.01,0.001,0.001 \%$; respectively. Besides, father's age positively influenced household health expenditures considering $1 \%$ significance level. Likewise, the level of parents' education had a positive impact on household health expenditures as the increase in the levels of education for the father of the household in families placed in the second, the third, the fourth, and the fifth categories led to an increase in household 
health expenditures by $1,0.2,0.1$, and $0.2 \%$; respectively. These values for the boost in the levels of mother's education for the same categories were equal to $1,0.3,0.1$, and $0.2 \%$; respectively.

The effect of the type of father's employment on household health expenditures was also significant so that the coefficients of father's employment variable in public and private sectors were respectively -0.095 and 0.121 , suggesting that father's employment in public sector reduced household health expenditures and employment in private sector increased such costs.

The variables of age, education, wage, and types of mother's employment were not statistically significant in the given model and their results could not be further interpreted and analyzed. The number of household members (i.e. family size) with a coefficient of 0.026 at the significance level of $1 \%$ had also a positive impact on household health expenditures as households in categories 2, 3, 4, and 5 respectively increased their household health expenditures by $0.5,0.1,0.05$, and $0.01 \%$ as one child was added to the household but households in the first category decreased their health expenditures as a new child had been added to the household. The coefficient of household 'Income Per Capita' variable was 0.125 , indicating a direct relation between household income per capita and household health expenditures, so that increased household income per capita led to an rising trend in household health expenditures by 0.2 , $0.6,0.2$, and $0.4 \%$ in the households in the categories 2, 3, 4, and 5; respectively.

Table 3 The coefficients and marginal effects of Ordered Probit

\begin{tabular}{|c|c|c|c|c|c|c|}
\hline Variables & Coefficients & $\begin{array}{l}\text { Marginal } \\
\text { effects } 1\end{array}$ & $\begin{array}{l}\text { Marginal } \\
\text { effects2 }\end{array}$ & $\begin{array}{l}\text { Marginal } \\
\text { effects3 }\end{array}$ & $\begin{array}{l}\text { Marginal } \\
\text { effects4 }\end{array}$ & $\begin{array}{l}\text { Marginal } \\
\text { effects5 }\end{array}$ \\
\hline Income Per Capita & $0.1257 * * *$ & $-0.0391 * * *$ & $0.0251 * * *$ & $0.0066^{* * *}$ & $0.0026^{* * *}$ & $0.0049 * * *$ \\
\hline Child's Gender & 0.0139 & -0.0043 & 0.0028 & 0.0007 & 0.0003 & 0.0005 \\
\hline Child's Age & -0.0050 & 0.0016 & -0.0010 & -0.0003 & -0.0001 & -0.0002 \\
\hline Child labor & $0.0010^{*}$ & $-0.0003^{*}$ & $0.0002 *$ & $0.0001^{*}$ & $0.0000^{*}$ & $0.0000 *$ \\
\hline School Children & $-0.0596^{* *}$ & $0.0189 * *$ & $-0.0120 * *$ & $-0.0032 * *$ & $-0.0013 * *$ & $-0.0024 * *$ \\
\hline Child's Education & -0.0002 & 0.0001 & 0.0000 & 0.0000 & 0.0000 & 0.0000 \\
\hline Father's Age & $0.0087 * * *$ & $-0.0027 * * *$ & $0.0017 * * *$ & $0.0005 * * *$ & $0.0002 * * *$ & $0.0003 * * *$ \\
\hline Father's Education & $0.0518 * * *$ & $-0.0161 * * *$ & $0.0104 * * *$ & $0.0027 * * *$ & $0.0011 * * *$ & $0.0020 * * *$ \\
\hline Father's Wage & 0.0000 & 0.0000 & 0.0000 & 0.0000 & 0.0000 & 0.0000 \\
\hline $\begin{array}{l}\text { Father's Public } \\
\text { Employment }\end{array}$ & $-0.0954 *$ & $0.0291 *$ & $-0.0189 *$ & $-0.0048^{*}$ & $-0.0018^{*}$ & $-0.0035^{*}$ \\
\hline $\begin{array}{l}\text { Father's Private } \\
\text { Employment }\end{array}$ & $0.1211 * * *$ & $0.0373 * * *$ & $0.0241 * * *$ & $0.0062 * * *$ & $0.0024 * * *$ & $0.0046^{* * *}$ \\
\hline Mother's Age & 0.0045 & -0.0014 & 0.0009 & 0.0002 & 0.0001 & 0.0002 \\
\hline $\begin{array}{l}\text { Mother's } \\
\text { Education }\end{array}$ & $0.0594 * * *$ & $-0.0185 * * *$ & $0.0119 * * *$ & $0.0031^{* * *}$ & $0.0012 * * *$ & $0.0023 * * *$ \\
\hline $\begin{array}{l}\text { Mother's } \\
\text { Employment }\end{array}$ & -0.0981 & 0.0297 & -0.0194 & -0.0049 & -0.0019 & -0.0035 \\
\hline Mother's Head & -0.0089 & 0.0028 & -0.0018 & -0.0005 & -0.0002 & -0.0003 \\
\hline Mother's Wage & 0.0000 & 0.0000 & 0.0000 & 0.0000 & 0.0000 & 0.0000 \\
\hline $\begin{array}{l}\text { Mother's Public } \\
\text { Employment }\end{array}$ & -0.0860 & 0.0261 & -0.0170 & -0.0043 & -0.0016 & -0.0031 \\
\hline $\begin{array}{l}\text { Mother's Private } \\
\text { Employment }\end{array}$ & 0.1365 & -0.0444 & 0.0275 & 0.0077 & 0.0031 & 0.0061 \\
\hline Family Size & $0.0261^{*}$ & $-0.0081 *$ & $0.0052^{*}$ & $0.0014^{*}$ & $0.0005^{*}$ & $0.0010^{*}$ \\
\hline$/$ cut $1=3.604$ & $/$ cut $2=4.497$ & $/$ cut $3=4.853$ & $/$ cut $4=5.057$ & & & \\
\hline
\end{tabular}

* Significance at 10\%., ** Significance at 5\%., *** Significance at $1 \%$. 


\section{Discussion}

The results in both models showed that child labor increased household health expenditures and families with school children spent less on health compared to those with child laborers. Given the fact that household health expenditures included two types, health care and medical expenditures, medical expenditures may be the reason for increasing family health expenditures with labor children, leading to deteriorated children's health status. These results were consistent with the findings of previous studies in the related literature [1,32-35].

At a $1 \%$ significance level, parental education by itself had a positive impact on household health expenditures (in both models). This conclusion suggested that households whose parents had higher levels of education were endowed with enhanced levels of health-related knowledge and consequently spent more on household health. These findings were consistent with the Grossman and Schultz theories [18,36] and in line with previous experimental studies [19,20,22,23,25-27,37]. The type of parental employment also affected household health expenditures, so that parental employment in private sector could increase household health expenditures and employment in public sector was likely to decrease household health expenditures. This outcome could be due to the difference in pays in private and public sectors since pays in private sector were higher than those in public sector which could consequently have a positive impact on household health expenditures. Employment of parents in private sector also led to spending more on health.

Among all the variables affecting health expenditures of households, the variable of income per capita had the greatest impact on health expenditures, i.e. the higher the household income per capita, the higher the share of household health expenditures. So, reduced health expenditures in some households could be due to the high expenses of health care services that could not be achieved considering household income. In this respect, Matsaganis et al [21], Savojipour et al [19], Sanwald and
Theurl [20], Olasehinde and Olaniyan [22], and Ahmadi et al [23] also showed that income had a positive impact on household health expenditures.

Furthermore, family size had a positive impact on household health expenditures in both models; in other words, if a new child was added to a family, the probability of increasing health expenditures would be higher that is consistent with findings reported in previous empirical studies [19-23]. The increase in household health expenditures is due to household members' higher need for health products and services.

The present study had some limitations. First, in addition to the variables included in the model, other variables also affected household health expenditure, which were not investigated in the present study due to lack of data. Second, household health expenditures were recorded according to household heads' responses to interviewers, and this case was also biased. Third, some of the variables affecting household health status such as parental wages, mother's employment, and female-headed household were not statistically significant in the models and the results could not be interpreted.

\section{Conclusions}

The findings of this study revealed that the entry of children into labor markets in both models had a positive impact on household health expenditures, so the authorities and health system planners are suggested to adopt policies and make decisions to eliminate child labor in order to inhibit complications will be caused by child labor in the future; otherwise, people in society as human capital involved in production will suffer from health problems, productivity will be reduced, and health expenditures will be increased, causing difficulties for these people and all other those in society. Moreover, given that child labor was a share of household income leading to an increase in household income and elimination of poverty, policies could 
be implemented to compensate for child labor and provide opportunities for further education among this age group. In addition, children's health and safety can be achieved by certain organizations and institutions.

According to research results, the household income per capita variable increased the probability of an increase in household health expenditures compared with other variables of models. According to this result, it seems that there is income inequality, so that people with higher income can enjoy more healthcare products and services and consequently spend more on it. By providing all types of social insurance for everyone and coverage of more goods and services by the health insurance, more people will have access to these products and services, and the income inequality will be reduced.

\section{Acknowledgments}

Would like to express thanks to anonymous referees, the authorities.

\section{Authors' contributions}

Study design: MSH

Data collection and analysis: MSH, SGH

Manuscript preparation: MSH, SGH

All authors have read and approved the final version.

\section{Conflict of interest}

"The authors declare that they have no competing interests."

\section{Funding}

The authors received no financial support for the research, authorship and/or publication of this article.

\section{Availability of data and materials}

The datasets used and/or analyzed during this study are available from the corresponding author on reasonable request.

\section{References}

1- Weerakoon R, Wijesinghe MDJW. The health consequences of child labour in Sri Lanka. International Journal of Scientific \& Technology Research2017; 6(9):
290-6.

2- International Labour Organization (ILO). Global estimates of child labour: results and trends, 2012-2016. Geneva: International Labour Office; 2017.

3- Keshavarz Haddad G. Parents' decision on child labour and school attendance: evidence from Iranian households. Journal of Education and Work2017; 30(6): 612-31.

4- O'Donnell O, Rosati FC, Van Doorslaer E. Health effects of child work: Evidence from rural Vietnam. $J$ Popul Econ2005; 18(3): 437-67.

5- Fassa AG, Facchini LA, Dall'agnol MM, Christiani DC. Child labor and health: problems and perspectives. Int J Occup Environ Health2000; 6(1): 55-62.

6- International Labour Organisation (ILO). A future without child labour. Geneva: International Labour Office; 2002.

7- Forastieri V. Children at work: health and safety risk. Geneva, International Labour Office; 1997.

8- Buonomo Zabaleta M. The impact of child labor on schooling outcomes in Nicaragua. Econ Educ Rev2011; 30(6): 1527-39.

9- Shahraki M, Ghaderi S. Survey of child workers decide to employment and education in Iran. Quantitative Economics2012; 9(4): 57-89.

10- Haddad GR, Ojaghi S. Parental bargaining power and child's time allocation among Iranian households. Iranian Journal of Economic Research2014; 19(60): 67-99.

11- Shahraki M, Ghaderi S. Investigation of mothers and child labor' decision on employment: Evidence from Iranian urban household. Quarterly Journal of Economic Growth and Development Research2018; 8(32): 125-38.

12- Rezaei S, Dindar A, Rezapour A. Health care expenditures and their determinants: Iran provinces (2006-2011). Journal of Health Administration2015; 19(63): 81-90.

13- Herwartz H, Theilen B. The determinants of health care expenditure: testing pooling restrictions in small samples. Health Econ2003; 12(2): 113-24.

14- Shahraki M. Estimation of supplementary health insurance demand in Iranian urban household: probit model with sample selection. Iran J Health Insur2019; 2(1): 10-6.

15- Magazzino C, Mele M. The determinants of health expenditure in Italian regions. Int J Econ Finance2012; 4(3): 61-72.

16- Di Matteo L. The macro determinants of health expenditure in the United States and Canada: assessing the impact of income, age distribution and time. Health Policy2005; 71(1): 23-42.

17-Samadi A, Homaie Rad E. Determinants of healthcare expenditure in economic cooperation organization 
(ECO) countries: evidence from panel cointegration tests. Int J Health Policy Manag2013; 1(1): 63-8.

18- Grossman M. On the concept of health capital and the demand for health. J Polit Econ1972; 80(2): 223-55

19- Savojipour S, Assari Arani A, Agheli L, Hassanzadeh A. The determinants of urban families' health expenditure. The Journal of Economic Policy2018; 10(19): 25-52.

20- Sanwald A, Theurl E. Out-of-pocket payments in the Austrian healthcare system- a distributional analysis. Int $J$ Equity Health2015; 14(1): 1-12.

21- Matsaganis M, Mitrakos T, Tsakloglou P. Modelling health expenditure at the household level in Greece. Eur $J$ Health Econ2009; 10(3): 329-36.

22- Olasehinde N, Olaniyan O. Determinants of household health expenditure in Nigeria. Int J Soc Econ2017; 44(12): 1694-709.

23- Ahmadi A, Nikravan A, Naseri A, Asari A. Effective determinants in household out of packet payments in health system of Iran, using two part regression model. Journal of Health Administration2014; 17(56): 7-18.

24- Rout HS. Socio-economic factors and household health expenditure: The case of orissa. Journal of Healthcare Management2008; 10(1): 101-18.

25- Toor IA, Butt MS. Determinants of health care expenditure in Pakistan. Pak Econ Soc Rev2005; 13(1): 133-50.

26- Muhammad Malik A, Azam Syed SI. Socio-economic determinants of household out-of-pocket payments on healthcare in Pakistan. Int J Equity Health2012; 11: 51.

27- Okunade AA, Suraratdecha C, Benson DA. Determinants of Thailand household healthcare expenditure: the relevance of permanent resources and other correlates. Health Econ2010; 19(3): 365-76.

28- Lee W-C, Jiang L, Phillips CD, Ohsfeldt RL.
Rural-urban differences in health care expenditures: empirical data from US households. Advances in Public Health2014; 2014: 1-8.

29- Shahraki M, Agheli L, Assari Arani A, Sadeqi $\mathrm{H}$, Ghaderi S. The relationship between mother's socioeconomic status and child health. Journal of Research and Health2018; 8(2): 143-51.

30- Salatin P, Mohammadi S. The impact of factors affecting the health expenditures in the provinces of Iran: panel data approach. Iranian Journal of Economic Research2015; 20(64): 177-207.

31- Shahraki M, Ghaderi S. Socioeconomic factors determining fruit and vegetable consumption among urban households in Iran. Journal of Research and Health2017; 7(4): 887-98.

32- Silva FdF, Teixeira EC, Lima JEd. The effect of the early entrance to job market on the health status of Brazilians in 2008: A robustness econometric test. Procedia Economics and Finance2013; 5: 241-50.

33- Wolff FC, Maliki. Evidence on the impact of child labor on child health in Indonesia, 1993--2000. Econ Hum Biol2008; 6(1): 143-69.

34- Ahmed S, Ray R. Health consequences of child labour in Bangladesh. Demogr Res2014; 30: 111-50.

35- Giuffrida AF. Iunes R, Savedoff W. Health and poverty in Brazil: estimation by structural equation model with latent variables. Washington DC: InterAmerican Development Bank; 2005.

36- Schultz TP. Studying the impact of household economic and community variables on child mortality. Popul Dev Rev1984; 10: 215-35.

37- Charity Agbo M. The health and educational consequences of child labour in Nigeria. Health Science Journal2017; 11(1): 1-9.

\footnotetext{
Copyright $(\mathcal{C} 2016$ ASP Ins. This open-access article is published under the terms of the Creative Commons Attribution-NonCommercial 4.0 International License which permits Share (copy and redistribute the material in any medium or format) and Adapt (remix, transform, and build upon the material) under the Attribution-NonCommercial terms.
} 